\title{
Nutrient intakes in socially disadvantaged groups in Ireland
}

\author{
BY PAULINE LEE \\ Division of Nutritional Sciences, Department of Clinical Medicine, Trinity College Medical \\ School, St James Hospital, Dublin 8, Irish Republic
}

Social disadvantage is a major risk factor for ill health, in terms of both morbidity and mortality, at all ages (Syme \& Berkman, 1976; Morris, 1979; Department of Health and Social Security, 1980; Holme et al. 1980; Whitehead, 1988).

In general children from the lower social classes tend to have lower birth weights (Alberman, 1981; Dowding, 1982), to be shorter and lighter than children from higher social classes (National Nutrition Survey, 1953; Owen et al. 1974; Department of Health and Social Security, 1975; Garn \& Clark, 1975; Nelson \& Naismith, 1979; Donnet et al. 1981; Hoey et al. 1987), and to have a higher caries experience (Hausen et al. 1982; Fergusson \& Horwood, 1986; Mansbridge \& Brown, 1986; Truin et al. 1986). There are indications in some countries that social class differences in height have diminished with improvements in socio-economic circumstances (Lindgren, 1976; Jones et al. 1985). However, recent growth data in Ireland show that in the lower socio-economic groups, children are still shorter at all ages than in the higher socio-economic groups (Hoey et al. 1987).

Examples of the social class gradient in disease incidence and mortality rates, at all ages, were seen in the Black report published in Britain in 1980 (Department of Health and Social Security, 1980) and in a follow-up report in 1988 (Whitehead, 1988). Both these reports also highlighted the fact that despite general improvements in living conditions in recent decades there has been a widening in health inequalities between social groups, especially in adults.

Several researchers have attempted to explain this social gradient in health by examining the relative exposure of socially disadvantaged groups to known risk factors, such as, smoking, alcohol intake, stress, and poor diet, but findings have rarely indicated simple relationships between the variables, particularly in the case of diet. For example, elevated levels of blood pressure and blood cholesterol are both risk factors for coronary heart disease and both these are associated with diet. But, when Cade et al. (1988) investigated the social class differences found in adult mortality rates from coronary heart disease, they found that differences in diet in middle age, in particular consumption of energy or fat, did not account for the difference in disease incidence. They suggest that the explanation may lie more in the differences in health and development of children in the past than in the quality of adult diets at present.

In general, findings from studies investigating differences in nutrient intakes between social classes have not been consistent. Some studies have shown no differences (Cook et al. 1973), while in the United States it was found that the absolute intakes of all nutrients decreased with decreasing income (Ten State Nutrition Survey (TSNS), 1973; Owen et al. 1974; Owen \& Owen, 1982). When the nutrient densities of these diets were calculated, it was discovered that the dietary problems of the lower socio-economic groups were related more to low food intakes rather than to the quality of their food. On the other hand, studies in Britain in the 1970 s found that children from lower 
socio-economic groups consumed approximately $418-544 \mathrm{~kJ}(100-130 \mathrm{kcal}) / \mathrm{d}$ more than their more affluent peers (Bransby \& Fothergill, 1954; Department of Health and Social Security, 1975; Black et al. 1976; Donnet et al. 1981). The inverse relationship in energy intakes has been attributed, in part, to the differences in energy expenditure associated with differences in social environment (Black et al. 1976). Nelson \& Paul (1981) suggested that the social and physical environment may act as a limiting factor on the effectiveness of diet in promoting growth and health, and that as a result more food may be necessary to sustain normal growth.

A number of recent Irish dietary studies have focused on low socio-economic groups or have included these groups in their study sample (McSweeney \& Kevany, 1982; Health Education Bureau, 1987; County Dublin Vocational Educational Committee, 1988; Lee, 1988; Lee \& Gibney, 1988; McLoughlin, 1988; Van Leishout, 1988). The purpose of the present review is to examine the findings of these studies, as they relate to different age-groups, and try to highlight the dietary problems which have been found to be associated with social disadvantage in this country.

\section{INFA NTS}

Although there has been a general resurgence in breast-feeding in developed countries over the past $10-20$ years, a distinct social class gradient has been observed with a significantly higher rate found among better-educated mothers from higher social groups (Martinez \& Nalezienski, 1979, 1981; Wharton, 1981; Black, 1983; Tanaka et al. 1987). In the national survey of infant feeding practices in Ireland (McSweeney \& Kevany, 1982) $32 \%$ of mothers were breast-feeding on discharge from hospital but the value for social groups 5 and 6 (non-skilled manual and unemployed) was only $17 \%$. A follow-up survey in 1985 (Health Education Bureau, 1987) indicated that the situation had not improved since the earlier study. Similar findings were reported from a Dublin Maternity Hospital (Joyce et al. 1984). Results from a recent study (Lee, 1988) show that in the most disadvantaged areas of Dublin, breast-feeding is practically non-existent, with only three of the 193 infants studied being breast-fed. Studies of infant feeding practices in lower socio-economic groups in Glasgow have shown similar findings (Donnet et al. 1981; McKillop \& Durnin, 1982; Angove, 1984).

Social class differences were also evident in the age at which cow's milk replaced formula milk and also the age at which solid foods were first introduced. In a lower socio-economic group studied by Lee (1988) $37 \%$ of infants had been weaned to cow's milk before 8 weeks and $49 \%$ before 12 weeks, whereas, in the national survey of mixed socio-economic-group infants (McSweeney \& Kevany, 1982) only $17 \%$ had been weaned to cow's milk by 8 weeks, rising to $30 \%$ at 16 weeks. A similar pattern was observed, in these studies, in the age at which solid foods were introduced; $47 \%$ of the low-socioeconomic-group infants had been given solid food before 3 months compared with only $26 \%$ of the mixed socio-economic group. Another disturbing fact to emerge was that only $9 \%$ of the low socio-economic-group infants, who had been transferred to cow's milk at an early age, had received vitamin supplements. Most of these infants had been given rusks or sometimes baby rice in the milk feeds presenting them with a very high solute load. Overall more than $70 \%$ of children in the study sample were having rusks at 10 months, although the consumption of other commercial baby foods was low, probably due to the high cost of these foods (Lee, 1988). 
From a nutritional point of view the diets of low-socio-economic-group infants appeared to be adequate to meet the needs of the majority of children and this was in agreement with most other comparable studies (Department of Health and Social Security, 1975; Black et al. 1976; Morgan \& Mumford, 1976; Donnet et al. 1981; McKillop \& Durnin, 1982; Owen \& Owen, 1982; Yeung et al. 1982). The widespread use of rusks had the effect of bridging some of the gap in micro-nutrient content between cow's milk given without vitamin or mineral supplements and formula or breast milk. In general low micro-nutrient intakes were found in children who were drinking doorstep milk but were not receiving either vitamin and mineral supplements or fortified baby foods (Lee, 1988).

\section{OTHER PRESCHOOL CHILDREN}

In a study of diets of preschool children living in disadvantaged areas of Dublin (Lee, 1988), it was found that while macro-nutrient intakes increased with age, as expected, intakes of many micro-nutrients actually decreased as the children moved from fortified baby foods onto an adult type diet. This trend was also observed in other studies of preschool children (Table 1). Compared with the British groups, Irish disadvantaged children had similar intakes of energy and iron, higher intakes of protein and calcium, but lower intakes of vitamin C. From available data on food sources it would appear that the difference in protein and calcium intakes can be accounted for by a higher milk consumption in Irish children. A lower intake of carbohydrate, in the form of biscuits and cakes, had the effect of balancing energy intakes. The lower vitamin $\mathrm{C}$ intakes were largely due to the fact that few of the younger children and none of the older ones had received vitamin supplements, whereas for example, on average $31 \%$ of the vitamin $C$ intakes in children in the Department of Health and Social Security (1975) study had come from supplements. Black et al. (1976) also noted the significant contribution of supplements to vitamin $\mathrm{C}$ intakes in their study (contributing between 27 and $52 \%$ ). However, in the Department of Health and Social Security (1975) study, children from lower socio-economic groups did not continue to receive vitamin supplements as they got older and their average vitamin $\mathrm{C}$ intake at $32 \mathrm{mg} / \mathrm{d}$, was very similar to the Irish value for the comparable group. The American low socio-economic group studied by Endozien et al. (1979) had higher intakes of all nutrients when compared with British or Irish children, this is possibly because they used a different assessment method. In other US studies of preschool children, vitamin $C$ intakes were found to be correlated with socio-economic status (Owen et al. 1974).

Although the mean intakes of $\mathrm{Fe}$ in disadvantaged Irish children was similar to that in the British groups, an examination of the distribution of intakes showed that $61 \%$ of the older preschool children had intakes below $75 \%$ of recommended dietary allowance (RDA) of $8 \mathrm{mg} / \mathrm{d}$ (Kevany, 1983). This may be cause for concern because the preschool child is at a crucial stage of development, when neo-natal Fe reserves are depleted and the requirement is increasing rapidly. Furthermore, $\mathrm{Fe}$ absorption from the diet may have been poor because of the low vitamin C intakes (Rossander et al. 1979; Dallman et al. 1980 ); $68 \%$ of the older children were found to consume less than $75 \%$ RDA and one-third less than $50 \%$ of the RDA of $45 \mathrm{mg} / \mathrm{d}$. Intakes of other micro-nutrients such as zinc, folate, and vitamin D were also low relative to the RDA. Relatively low Fe and vitamin $C$ intakes were also observed in Irish preschool children who participated in the Tallaght Study of low-income families (Lee \& Gibney, 1988). 


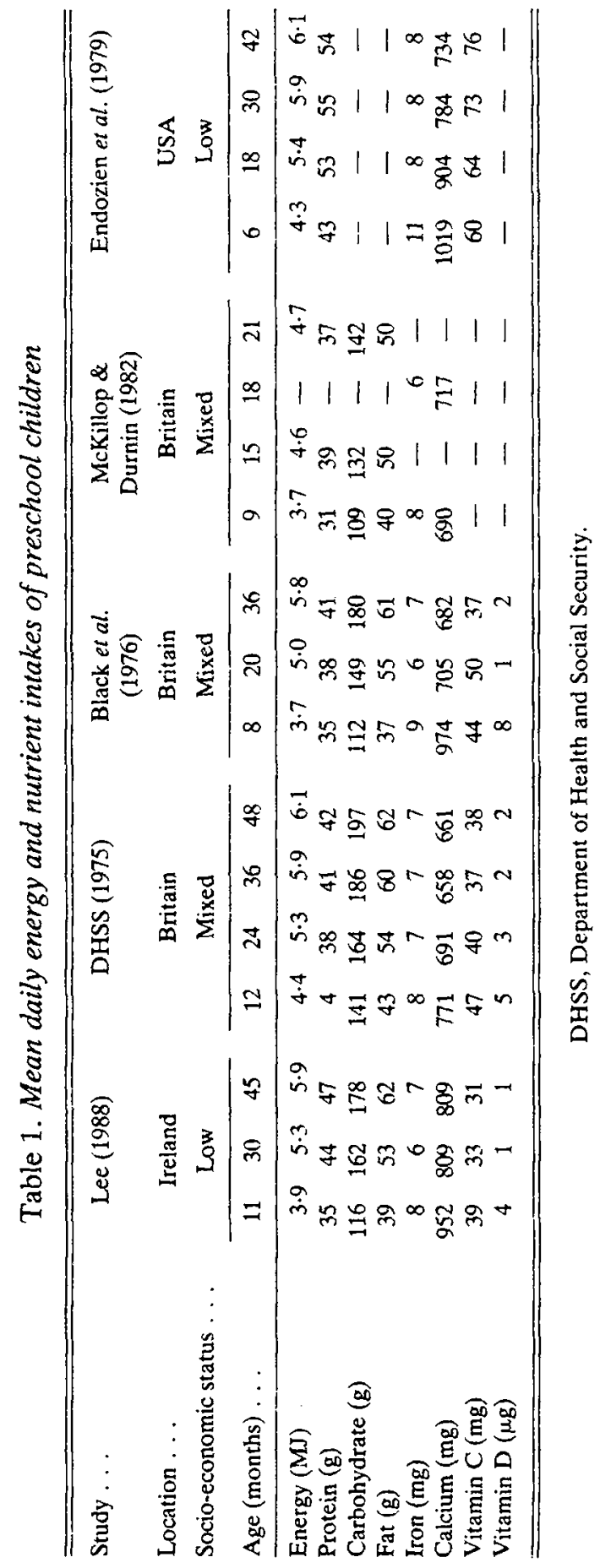


Table 2. Daily energy, iron and vitamin $C$ intakes of children aged 4-12 years

\begin{tabular}{|c|c|c|c|c|c|c|}
\hline Study & \multicolumn{2}{|c|}{ Lee \& Gibney (1988) } & $\begin{array}{c}\text { Connolly } \\
\text { et al. } \\
(1980)\end{array}$ & $\begin{array}{l}\text { Black } \\
\text { et al. } \\
(1976)\end{array}$ & \multicolumn{2}{|c|}{$\begin{array}{c}\text { Dutch National } \\
\text { Food Survey (1988) }\end{array}$} \\
\hline Location . . & \multicolumn{2}{|c|}{ Ireland (Dublin) } & $\begin{array}{c}\text { Ireland } \\
\text { (Co. Cork) }\end{array}$ & Britain & \multicolumn{2}{|c|}{ Netherlands } \\
\hline Socio-economic status . . . & \multicolumn{2}{|c|}{ Low } & Mixed & Mixed & \multicolumn{2}{|c|}{ Mixed } \\
\hline Age-range & $\begin{array}{c}4-7 \text { years } \\
(n 20)\end{array}$ & $\begin{array}{c}7-12 \text { years } \\
(n \text { 47) }\end{array}$ & $\begin{array}{c}\text { 3-9 years } \\
(n 56)\end{array}$ & $\begin{array}{l}5 \text { years } \\
(n 26)\end{array}$ & $\begin{array}{l}4-6 \text { years } \\
(n 254)\end{array}$ & $\begin{array}{c}7-9 \text { years } \\
(n \text { 246) }\end{array}$ \\
\hline Energy (MJ) & 8.5 & $9 \cdot 7$ & 7.9 & $6 \cdot 7$ & $7 \cdot 2$ & $8 \cdot 2$ \\
\hline Iron (mg/10 MJ energy) & $10 \cdot 3$ & $10 \cdot 2$ & $10 \cdot 6$ & 11.9 & $10 \cdot 3$ & $10 \cdot 5$ \\
\hline Vitamin $\mathrm{C}(\mathrm{mg} / 10 \mathrm{MJ}$ energy) & 50 & 52 & 61 & 81 & 82 & 70 \\
\hline
\end{tabular}

While it is difficult to draw any definitive conclusions about the extent of micronutrient inadequacies in the lower social-class Irish children, the combination of low $\mathrm{Fe}$, vitamin $\mathrm{C}$ and folate intakes are likely to increase the risk of anaemia for these children.

\section{CHILDREN AGED 4-12 YEARS}

Table 2 compares the intakes of energy, $\mathrm{Fe}$ and vitamin $\mathrm{C}$, in a socially disadvantaged group of Irish children with data from other studies. As can be seen energy intakes were higher in the lower-social-class children. This could be because these children ate more, but it is more likely to be due to differences in dietary assessment techniques. The diet-history method was used in the Tallaght Study (Lee \& Gibney, 1988) of low-income families, whereas most other studies used the weighed-intakes method over periods of 3-7 d. The history method has been found, in many cases, to give higher mean values than the weighed-intakes method (Jain et al. 1980), but it has not been established which method gives more accurate assessment of actual habitual dietary intakes. It is interesting to note that in a study of children in France where the dietary-history method was also used (Rolland-Cachera \& Bellisle, 1986), energy intakes were similar to those recorded in the Tallaght Study (Lee \& Gibney, 1988). To facilitate comparisons between the different study groups, vitamin $\mathrm{C}$ and $\mathrm{Fe}$ consumption are expressed in terms of intakes per $10 \mathrm{MJ}$ energy. Results show that the Fe densities of diets in the lower-socialclass Irish children tended toward the bottom end of the range and vitamin $C$ densities were below those recorded in other studies. A study which examined the nutritional quality of packed lunches in Dublin schools (McLoughlin, 1988) also showed that lower-social-class children had poorer quality lunches than the higher-social-class children.

Despite the poorer quality diets, however, an examination of the mean and distribution intakes in the Tallaght Study (Lee \& Gibney, 1988) showed that for most nutrients, the majority of study children consumed more than $75 \%$ of the RDA, indicating that they were reasonably well nourished. 


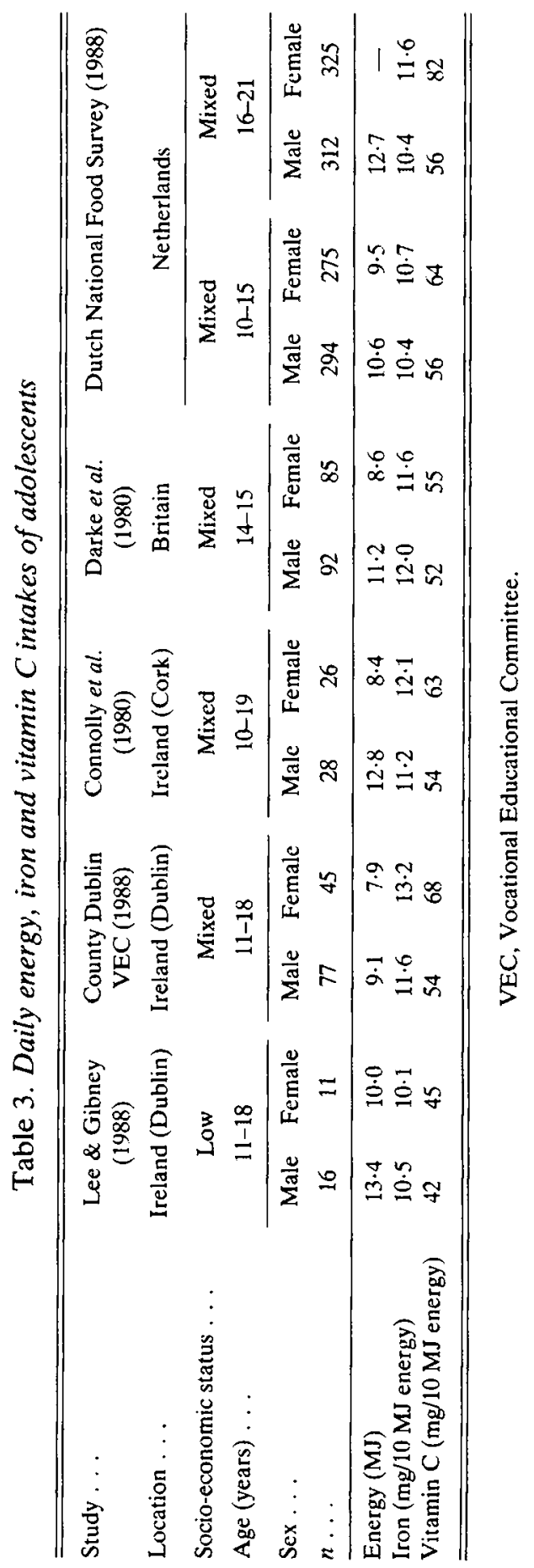




\section{ADOLESCENTS}

Table 3 shows the intakes of energy, Fe and vitamin $\mathrm{C}$ in a socially disadvantaged group of Irish adolescents compared with similar values from other studies. As in the younger age-group, energy intakes were higher in the lower-social-class children, probably because of the dietary assessment method used. Also, the Fe densities of the diets tended toward the bottom end of the range, while vitamin $C$ densities were lower than those recorded in other studies. An examination of the distribution of $\mathrm{Fe}$ and vitamin $\mathrm{C}$ intakes showed that many lower-social-class adolescent girls may have inadequate intakes; $45 \%$ had $\mathrm{Fe}$ intakes below $75 \%$ of their RDA, and $55 \%$ had vitamin $\mathrm{C}$ intakes below this level. These findings are not in agreement with those of the County Dublin Vocational Educational Committee (1988) study which showed no significant difference in nutrient intakes between socio-economic groups. However, the data were only analysed for the combined groups of males and females and no information was given on the distribution of intakes, making it difficult to evaluate the differences in findings between the two studies.

From the available data, and with the possible exception of $\mathrm{Fe}$ and vitamin $\mathrm{C}$ intakes in girls, it appears that disadvantaged adolescents are adequately nourished, in spite of the fact that meeting their dietary needs puts the low-income family under severe financial pressure. Our social welfare system does not make any allowance for the additional dietary requirements of the older child when making social welfare payments. Families with several older children receive the same allowance as do families with the same number of younger children. In the study of low-income families in Tallaght it was calculated that the cost of feeding a 12-year-old child consuming $10.5 \mathrm{~kJ}(2.5 \mathrm{kcal}) / \mathrm{d}$ was IR£11.90 (Lee \& Gibney, 1988) which is well above the social welfare allowances made for that child (IRf8.00-9.50).

\section{ADULTS $>18$ YEARS}

In Table 4 mean nutrient intakes of adult males in the Tallaght Study of low-income families (Lee \& Gibney, 1988) are compared with similar data recorded for adult males of mixed social classes studied in the Kilkenny Health Project (Gibney et al. 1989). As can be seen the intakes of energy, protein, fat, fibre and Fe are very similar, $\mathrm{Ca}$ intakes are higher in the Tallaght group (Lee \& Gibney, 1988), due to a higher milk consumption, but intakes of other micro-nutrients are lower. In the case of vitamin A, the lower intakes are of no concern because in both studies intakes were well above the RDA of $750 \mu \mathrm{g}$. Similarly, while the average intake of vitamin C in Tallaght males (Lee \& Gibney, 1988) was $30 \mathrm{mg}$ below the Kilkenny males (Gibney et al. 1989), this lower intake was in line with the RDA and an examination of the distribution of intakes showed that only $19 \%$ had intakes below $75 \%$ RDA.

Unfortunately the diets of Tallaght women (Lee \& Gibney, 1988) did not compare so favourably with the Kilkenny group (Gibney et al. 1989) (Table 5). While energy intakes were again similar for the two groups and Ca intakes were higher in the Tallaght group, protein, fibre, and a number of micro-nutrient intakes were considerably lower in Tallaght women (Lee \& Gibney, 1988). Of particular concern were the relatively lower intakes of fibre, Fe and vitamin $\mathrm{C}$. An average fibre intake of $14 \mathrm{mg}$ was well below the minimum $25 \mathrm{~g} / \mathrm{d}$ recommended by the Food Advisory Committee (1984). The distribution of Fe and vitamin C intakes showed that $31 \%$ of Tallaght females consumed less 
Table 4. Mean daily intakes of selected nutrients for adult males from low-income families in Tallaght compared with similar data from the Kilkenny Health Project

\begin{tabular}{|c|c|c|c|c|}
\hline \multirow{3}{*}{ Socio-economic status . . . } & \multirow{2}{*}{\multicolumn{2}{|c|}{$\begin{array}{c}\text { Tallaght study* } \\
\qquad \begin{array}{c}(n 42) \\
\text { Low }\end{array}\end{array}$}} & \multirow{2}{*}{\multicolumn{2}{|c|}{$\begin{array}{c}\text { Kilkenny study }{ }^{\dagger} \\
(n \text { 30) } \\
\text { Mixed }\end{array}$}} \\
\hline & & & & \\
\hline & Mean & SD & Mean & SD \\
\hline Energy (MJ) & $13 \cdot 1$ & $3 \cdot 0$ & $12 \cdot 5$ & $2 \cdot 6$ \\
\hline Protein $(g)$ & 100 & 25 & 107 & 22 \\
\hline Fat $(\mathrm{g})$ & 128 & 33 & 119 & 35 \\
\hline Carbohydrate (g) & 409 & 128 & 344 & 88 \\
\hline Fibre (g) & 22 & 6 & 24 & 6 \\
\hline$\%$ Protein energy & $13 \cdot 0$ & 1.7 & $16 \cdot 0$ & $2 \cdot 6$ \\
\hline \% Fat energy & $38 \cdot 2$ & $7 \cdot 3$ & $38 \cdot 8$ & $6 \cdot 3$ \\
\hline$\%$ Carbohydrate energy & $48 \cdot 7$ & 8.4 & $45 \cdot 7$ & $7 \cdot 8$ \\
\hline Iron $(\mathrm{mg})$ & $13 \cdot 5$ & $3 \cdot 2$ & $13 \cdot 1$ & $6 \cdot 5$ \\
\hline Calcium $(\mathrm{mg})$ & 1233 & 434 & 1026 & 364 \\
\hline Zinc (mg) & $12 \cdot 9$ & $3 \cdot 6$ & $15 \cdot 1$ & $3 \cdot 9$ \\
\hline Vitamin $A(\mu g R E)$ & 1507 & 1299 & 1180 & 677 \\
\hline Vitamin C (mg) & 60 & 21 & 89 & 25 \\
\hline Vitamin $B_{6}(\mathrm{mg})$ & $1 \cdot 5$ & $0 \cdot 3$ & 1.9 & 0.4 \\
\hline Folate $(\mu \mathrm{g})$ & 211 & 96 & 237 & 60 \\
\hline
\end{tabular}

$R E$, retinol equivalent.

* Lee \& Gibney (1988).

$\dagger$ Gibney et al. (1989).

than $50 \%$ of the RDA for Fe $(14 \mathrm{mg} / \mathrm{d})$ and $18 \%$ consumed less than $50 \%$ of the RDA for vitamin $\mathrm{C}(60 \mathrm{mg} / \mathrm{d})$. A low intake of $\mathrm{Fe}$ among women is not uncommon (Barber et al. 1985) but levels recorded in low-income Dublin women were a particular cause for concern.

$\mathrm{Zn}$ and folate intakes were also lower in Tallaght men and women (Lee \& Gibney, 1988 ) compared with the Kilkenny adults (Gibney et al. 1989). However, the uncertainty about actual requirements of these nutrients makes it impossible to evaluate the adequacy of intakes. Some studies have shown that despite low levels of these nutrients being recorded, few clinical signs of malnutrition were observed (Poh Tan et al. 1984; McNulty et al. 1987).

When a closer look was taken at various subgroups of women in Tallaght it was found that those at most risk of nutritional inadequacy were single mothers and deserted wives (Lee \& Gibney, 1988). Intakes of energy and most nutrients were lower for this group when compared with the total sample of women. The main exception was vitamin C where mean intakes were similar. Fe consumption was particularly low averaging at 6.9 $\mathrm{mg} / \mathrm{d}$ compared with $8.1 \mathrm{mg} / \mathrm{d}$ in the total sample of women, and $55 \%$ had $\mathrm{Fe}$ intakes below $50 \%$ RDA compared with $31 \%$ in the total sample. These low intakes were accounted for by very low meat consumption.

Because of the low nutrient intakes recorded in single mothers the diets of their children were compared with those of the total sample of children, but no differences were found indicating that these children did not share the nutritional disadvantage of their mothers. 
In Table 6 the average daily intakes of selected nutrients for adults in low-income families in Tallaght (Lee \& Gibney, 1988) are compared with similar data from other studies of mixed socio-economic groups. In general energy intakes are in agreement with those recorded in Kilkenny (Gibney et al. 1989), Orkney Islands (Barber et al. 1986), Moorpark (Connolly et al. 1980) and the Netherlands (Dutch National Food Survey, 1988). For males, protein and fat intakes were also similar in these groups, but females in the lower socio-economic group consumed less protein and fat than their counterparts in other study groups. Nevertheless, fat still contributed $37 \%$ to dietary energy in females, which is above the recommended value of $35 \%$. Carbohydrate intakes were higher in both males and females in the Tallaght Study (Lee \& Gibney, 1988) than in any of the other studies.

With the exception of males in the Netherlands (Dutch National Food Survey, 1988), mean fibre intakes in all study groups were below the minimum level of $25 \mathrm{~g} / \mathrm{d}$ suggested by the Food Advisory Committee (1984). Fibre intakes were in general lower in women than in men being lowest in women in low-income families in Tallaght (Lee \& Gibney, 1988). Males and females in the Tallaght Study (Lee \& Gibney, 1988) also had very low vitamin $C$ intakes in comparison with a number of other studies, and here again females appeared to be worst. Fe intakes were considerably lower in Tallaght females (Lee \& Gibney, 1988) than in any of the other groups.

\section{PREGNANT TRAVELLING WOMEN}

A study by Van Leishout (1988) compared the daily intakes of selected nutrients in pregnant travelling (itinerant) women with similiar data for pregnant settled women of low socio-economic status. The aim of the study was to identify differences in behaviour due to contraints other than economic, that might account for higher infant morbidity and mortality rates found among the travelling community. However, it was found that intakes of energy and all nutrients were higher in the traveller women suggesting that differences in diet could not account for the differences in health of their infants.

\section{FOOD INTAKE PATTERNS IN LOW SOCIO-ECONOMIC GROUPS}

The diets of disadvantaged groups were characterized by a high consumption of milk and table sugar, and a low fresh meat, fruit and vegetable consumption. In general diets were very monotonous varying little from week to week. A limited range of foods was consumed with emphasis on cheaper staple foods which are high in energy such as potatoes and bread.

\section{SUMMARY OF FINDINGS}

In the present review three groups have been identified as being particularly vulnerable to nutritional inadequacies. These are preschool children, adolescent girls and women, especially single mothers.

Low $\mathrm{Fe}$ and vitamin $\mathrm{C}$ intakes were common in the three groups and fibre was particularly low in women. For a large proportion of preschool children $\mathrm{Zn}$, folate and vitamin $\mathrm{D}$ intakes were also found to be well below the RDA, principally because of the high requirement for these nutrients at this rapid stage of growth. $\mathrm{Zn}$ and folate intakes 
Table 5. Mean daily intakes of selected nutrients for adult females from low-income families in Tallaght compared with similar data from the Kilkenny Health Project

\begin{tabular}{|c|c|c|c|c|}
\hline \multirow{3}{*}{ Socio-economic status . } & \multirow{2}{*}{\multicolumn{2}{|c|}{$\begin{array}{l}\text { Tallaght study* } \\
\qquad \begin{array}{c}(n 55) \\
\text { Low }\end{array}\end{array}$}} & \multirow{2}{*}{\multicolumn{2}{|c|}{$\begin{array}{l}\text { Kilkenny study }{ }^{\dagger} \\
\qquad(n 30) \\
\text { Mixed }\end{array}$}} \\
\hline & & & & \\
\hline & Mean & SD & Mean & SD \\
\hline Energy (MJ) & $8 \cdot 5$ & $2 \cdot 8$ & 8.4 & $2 \cdot 2$ \\
\hline Protein $(\mathrm{g})$ & 64 & 18 & 77 & 22 \\
\hline Fat $(\mathrm{g})$ & 81 & 24 & 87 & 28 \\
\hline Carbohydrate (g) & 275 & 1.31 & 232 & 67 \\
\hline Fibre $(g)$ & 14 & 5 & 20 & 9 \\
\hline$\%$ Protein energy & $13 \cdot 5$ & 3.7 & $15 \cdot 8$ & $3 \cdot 4$ \\
\hline$\%$ Fat energy & $37 \cdot 0$ & $7 \cdot 5$ & 39.6 & 4.9 \\
\hline$\%$ Carbohydrate energy & $49 \cdot 6$ & 9.8 & $44 \cdot 4$ & 5.5 \\
\hline Iron (mg) & $8 \cdot 1$ & $2 \cdot 3$ & $10 \cdot 3$ & $4 \cdot 2$ \\
\hline Calcium (mg) & 905 & 355 & 761 & 252 \\
\hline Zinc (mg) & $8 \cdot 3$ & $2 \cdot 5$ & 11.8 & $4 \cdot 5$ \\
\hline Vitamin $A(\mu g R E)$ & 1070 & 1032 & 1088 & 1030 \\
\hline Vitamin C (mg) & 45 & 18 & 73 & 32 \\
\hline Vitamin $B_{6}(\mathrm{mg})$ & 1.0 & $0 \cdot 3$ & $1 \cdot 3$ & 0.4 \\
\hline Folate $(\mu \mathrm{g})$ & 137 & 42 & 166 & 60 \\
\hline
\end{tabular}

RE, retinol equivalent.

* Lee \& Gibney (1988).

† Gibney el al. (1989).

were lower in the lower social classes for other age-groups as well, but it is difficult to evaluate the adequacy of these intakes because of the uncertainty about the actual requirements. In addition to these socially related dietary problems, and in common with the rest of the Irish population, fat intakes exceeded the recommended value of $35 \%$ of energy, and fibre intakes were below the recommended minimum of $25 \mathrm{~g} / \mathrm{d}$.

The findings of low $\mathrm{Fe}$ and vitamin $\mathrm{C}$ intakes in a number of disadvantaged groups would indicate an urgent need for a community-based programme to establish the true incidence of clinical anaemia.

\section{SUGGESTED INTERVENTION STRATEGY}

To achieve optimum nutrition for socially disadvantaged groups in this country a number of approaches may be necessary.

Obviously it would help if poverty were alleviated by increasing the payments made to social welfare recipients, particularly to families where there are a number of older children. Indications are, however, that it is unlikely that any major changes in the social welfare system will occur in the near future. There is a commonly held belief that much of the poverty in the lower social classes is due to mismanagement of funds. However, this theory is not supported by data from recent studies of disadvantaged groups which indicate that the majority of families were having a reasonably balanced diet despite very low incomes. Presumably this was through careful budgeting. 


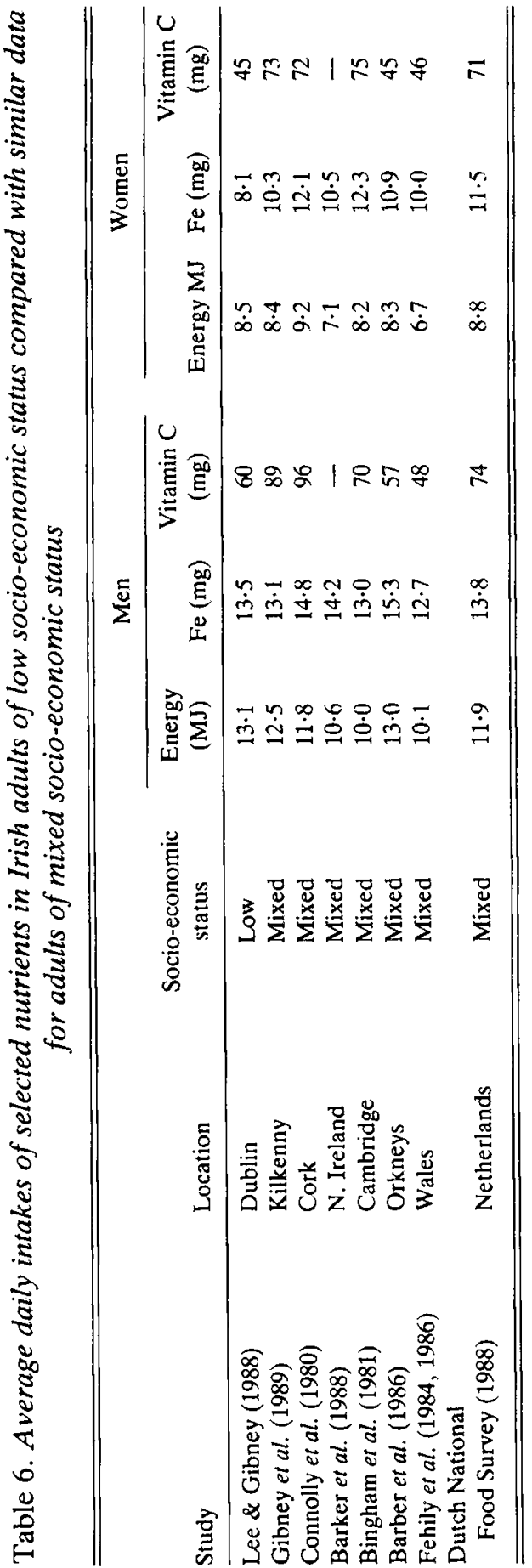


Other possible ways to improve the levels of nutrient intakes are dietary supplementation or nutrition education, or both. Dietary supplementation may be necessary on the basis that it may not be possible, because of lack of money, for some families to provide the type of diet that would ensure optimum nutrition. For preschool children up to the age of 5 years, this could take the form of multi-vitamin and multi-mineral drops which could be provided free of charge to medical card holders. The main problem with this solution is that as was seen from the data on early infant feeding habits of disadvantaged children, the uptake of supplements in these groups is very poor. Something else which might be worth considering is Fe fortification of flour, as is done in Britain. This presumably would benefit all age-groups as bread consumption is generally very high in the lower social classes.

A nutrition education programme which was designed specifically for use in disadvantaged areas of Dublin has been shown to be effective in improving dietary intakes in preschool children (Lee, 1988). Much of the success of this programme has been attributed to the fact that the dietary recommendations were feasible and took into account the limitations of the disadvantaged environment. For a nutrition education programme to be effective with disadvantaged groups, the dietary advice given has to be realistic and be based on the current dietary habits and customs of the target group. While many of the dietary problems of the socially disadvantaged are similar to those of the population as a whole, such as low fibre and high fat intakes, they have to be tackled slightly differently. For example meat and dairy products are usually targeted when attempting to lower fat intake. But, considering the value of meat as a source of high-quality $\mathrm{Fe}$, and the low Fe density of the diets in low-income families, a reduction of meat consumption is not desirable. It could be suggested that poor-quality meat and meat products be replaced with lean red meat, but this is not practical for families on limited incomes. Milk is another common target for reducing fat intakes, but because of its contribution to the adequate intakes of many nutrients such as $\mathrm{Ca}$, high-quality proteins and many vitamins, any nutrition education campaign which caused milk consumption to fall would be counterproductive. Findings from the study of low-income families in Tallaght (Lee \& Gibney, 1988) showed that about $60 \%$ of the difference in fat intake of high and low fat consumers could be accounted for by differences in butter consumption. Thus, butter would be a better target than meat for lowering fat intakes in disadvantaged groups (Lee \& Gibney, 1988).

\section{CONCLUSION}

Many of the dietary problems of the socially disadvantaged are similar to those seen in the Irish population as a whole, such as low fibre, and high fat intakes. But there are also socially related problems such as low $\mathrm{Fe}$ and vitamin $\mathrm{C}$ intakes in young children, adolescent girls and women. These are due mainly to a low consumption of fresh meat, fruit and vegetables. Appropriate nutrition intervention with these groups may help improve their nutrient intakes, which in turn may improve their health and, thus, help redress some of the balance in health between the social classes.

\section{REFERENCES}

Alberman, E. (1981). The influence of social environment on the nutrition of mother and child. In Preventive Nutrition and Society, pp. 95-108 [M. R. Turner, editor]. London: Academic Press. 
Angove, R. (1984). The role of the community dietitian in a multi-disciplinary approach to nutrition education in an area of multiple deprivation. Human Nutrition: Applied Nutrition 38A, 5-16.

Barber, S. A., Bull, N. L. \& Buss, D. H. (1985). Low iron intakes among young women in Britain. British Medical Journal 290, 743-744.

Barber, S. A., Bull, N. L. \& Cameron, A. M. (1986). A dietary survey of an isolated population in the U.K.: the Islanders of Orkney. Human Nutrition: Applied Nutrition 46A (6), 462-469.

Barker, M. E., McClean, S. I., McKenna, P. G., Reid, N. G., Strain, J. J., Thompson, K. A., Williamson, A. P. \& Wright, M. E. (1988). Diet, lifestyle and health in Northern Ireland: A report to the Health Promotion Research Trust. Belfast: U.U. and H.P.R.T. Publishers.

Bingham, S., McNeil, N. I. \& Cummings, J. H. (1981). The diet of individuals: a study of a randomly-chosen, cross-section of British adults in a Cambridgeshire village. British Journal of Nutrition 45, 23-35.

Black, A. E. (1983). Infant Feeding for the 1980 's. Report on a one day conference organised by the Department of Health and Social Security 16th June, 1982. Human Nutrition: Applied Nutrition 37A, $72-74$.

Black, A. E., Billewiez, W. Z. \& Thompson, A. M. (1976). The diets of pre-school children in Newcastle upon Tyne 1968-1971. British Journal of Nutrition 35, 105-113.

Bransby, E. R. \& Fothergill, J. E. (1954). Diets of young children. British Journal of Nutrition 8, 195-204.

Cade, J. E., Barker, D. J. P., Margetts, B. M. \& Morris, J. A. (1988). Diet and inequalities in health in three English towns. British Medical Journal 296, 1359-1362.

Connolly, J. F., Kevany, J. P., Brady, L. B., Stewart, D. \& Harrington, D. (1980). Dietary, biochemical and anthropometric effects of dairy products on selected family groups. Irish Journal of Science and Technology 4, 143-172.

Cook, J., Altman, D. G., Moore, D., Topp, S. \& Holland, W. W. (1973). A survey of the nutrition status of school children. British Journal of Preventive Social Medicine 27, 91-99.

County Dublin Vocational Educational Committee (1988). A Study of Adolescent Nutrition, and the Implications for Education. County Dublin V.E.C., Main Road, Dublin 24.

Dallman, P. R., Siimes, M. A. \& Stekel, A. (1980). Iron deficiency in infancy and childhood. American Journal of Clinical Nutrition 33, 86-118.

Darke, S. J., Disselduff, M. M. \& Try, G. P. (1980). Frequency distributions of mean daily intakes of food energy and selected nutrients obtained during nutrition surveys of different groups of people in Great Britain between 1968 and 1971. British Journal of Nutrition 44, 243-252.

Department of Health and Social Security (1975). A Nutrition Study of Pre-school Children. Report on Health and Social Subjects no. 10. London: H.M. Stationery Office.

Department of Health and Social Security (1980). Inequalities in Health. Report of a Research Working Group Chaired by Sir Douglas Black. London: Department of Health and Social Security.

Donnet, M. L., Cole, T. J., Scott, T. M. \& Standfield, J. P. (1981). Diet, growth and health of infants in a disadvantaged inner city environment in Glasgow. In Preventive Nutrition and Society [M. R. Turner, editor]. London: Academic Press.

Dowding, V. (1982). Distribution of birthweight in seven Dublin maternity units. British Medical Journal 284, 1901-1904.

Dutch National Food Survey (1988). Centrale Directie Voorlichting, Documentatie en Bibliotheek van hat ministerie van Welzijn, Volksgezondheid en Cultuur. Rijswijk.

Endozien, J. C., Switzer, B. R. \& Bryan, R. B. (1979). Medical evaluation of the special supplemental food program for women, infants and children. American Journal of Clinical Nutrition 32, 677-692.

Fehily, A. M. \& Bird, G. (1986). The dietary intakes of women in Caerphilly, South Wales: a weighed and photographic method compared. Human Nutrition: Applied Nutrition 40A (4), 300-307.

Fehily, A. M., Phillips. K. M. \& Sweetman, P. M. (1984). A weighed dietary survey of men in Caerphilly, South Wales. Human Nutrition: Applied Nutrition 38A (4), 270-276.

Fergusson, D. M. \& Horwood, L. J. (1986). Relationships between exposure to additional fluoride, social background and dental health in 7 year old children. Community Dentistry and Oral Epidemiology 14, $48-52$.

Food Advisory Committee (1984). Guidelines for Preparing Information and Advice to the General Public on Healthy Eating. Dublin: Department of Health, Public Health Division.

Garn, S. M. \& Clark, D. C. (1975). Nutrition, growth, development and maturation: findings from the Ten-State Nutrition Survey of 1968-1970. Pediatrics 56 (2), 306-319.

Gibney, M. J., Moloney, M. \& Shelley, E. (1989). The Kilkenny Health Project: food and nutrient intakes in a randomly selected group of healthy adults. British Journal of Nutrition 61, 129-137. 
Hausen, H., Milen, A., Heinonen, O. P. \& Paunio, I. (1982). Caries in primary dentition and social class in high and low fluoride areas. Community Dentistry and Oral Epidemiology 10, 33-36.

Health Education Bureau (H.E.B.) (1987). Low rates of breast-feeding in Ireland. In H.E.B. News Winter/Spring Edition, pp. 12-13. Dublin: Health Education Bureau.

Hoey, H., Tanner, J. M. \& Cox, L. A. (1987). Irish clinical growth standards. Acta Paediatrica Scandinavica (Suppl.) 338, 3-31.

Holme, I., Helgeland, A.. Hjermann, I., Laren, P. \& Lund-Larsen, P. G. (1980). Four-year mortality by some socio-economic indicators: the Oslo Study. Journal of Epidemiology and Community Health 34, 48-52.

Jain, M., Howe, G. R., Johnson, K. C. \& Miller, A. B. (1980). Evaluation of a diet history questionnaire for epidemiologic studies. American Journal of Epidemiology 111 (2), 212-219.

Jones, D. Y., Nesheim, M. C. \& Habicht, J. P. (1985). Influences in child growth associated with poverty in the 1970's: an examination of HANES I and HANES II cross-sectional US national surveys. American Journal of Clinical Nutrition 42, 714-724.

Joyce, N. M., Henry, G. R. \& Kelly, A. (1984). Infant feeding practices - Rotunda Hospital, 1979/80. Irish Medical Journal 77 (2), 45-48.

Kevany, J. (1983). Recommended Dietary Allowances. Dublin: Health Education Bureau.

Lee, P. (1988). Nutrition intervention in pre-school children. Ph.D. Thesis, Trinity College Dublin.

Lee, P. \& Gibney, M. J. (1988). Patterns of Food and Nutrient Intake in a Suburb of Dublin with Chronically High Unemployment. Dublin: Combat Poverty Agency.

Lindgren, G. (1976). Height, weight and menarche in Swedish urban school children in relation to socio-conomic and regional factors. Annals of Human Biology 3, 510-528.

McKillop, F. M. \& Durnin, J. V. G. A. (1982). The energy and nutrient intake of a random sample (305) of infants. Human Nutrition: Applied Nutrition 36A, 405-421.

McLoughlin, B. (1988). The Nutritional Quality of Children's School Packed Lunches in Dublin City and County. M.Sc. Thesis, Trinity College Dublin.

McNulty, H., McPartlin, J. M., Weir, D. G. \& Scott, J. M. (1987). Folate catabolism in normal subjects. Human Nutrition: Applied Nutrition 41A, 338-341.

McSweeney, M. \& Kevany, J. (1982). Nutrition Beliefs and Practices in Ireland. Dublin: Research and Information Division, Health Education Bureau.

Mansbridge, J. N. \& Brown, M. D. (1986). Changes in dental caries prevalence in Ayr children over 25 years and a comparison with Edinburgh children over the same period. Community Dental Health 3, 41-52.

Martinez, G. A. \& Nalezienski, J. P. (1979). The recent trend in breast-feeding. Pediatrics 64 (5), $686-692$.

Martinez, G. A. \& Nalezienski, J. P. (1981). 1980 update: the recent trend in breast-feeding. Pediatrics 67, $260-263$

Morgan, J. \& Mumford, P. (1976). Feeding practices and food intake of children under two years of age. Proceedings of the Nutrition Society 36, 47A.

Morris, J. N. (1979). Social inequalities undiminished. Lancet i, 87-90.

National Nutrition Survey (1953). Department of Health. Dublin: Stationery Office.

Nelson, M. \& Naismith, D. (1979). The nutritional status of poor children in London. Journal of Human Nutrition 33, 33-45.

Nelson, M. \& Paul, A. A. (1981). Socio-cconomic influences of nutrient intake in children. In Preventive Nutrition and Society [M. E. Turner, editor]. London: Academic Press.

Owen, G. M., Kram, K. M., Garry, P. J., Lowe, J. E. \& Lubin, A. H. (1974). A study of nutritional status of pre-school children in the United States, 1968-1970. Pediatrics Supplement 53 (4), Part II, 597-646.

Owen, G. M. \& Owen, A. L. (1982). Nutritional Status of North Americans. In: Human Nutrition. Current Issues and Controversies, pp. 73-86 [A. Neuberger and T. H. Jukes, editors]. Lancaster: MTP Press Ltd.

Poh Tan, S., Wenlock, R. W. \& Buss, D. H. (1984). Folic acid content of the diet in various types of British households. Human Nutrition: Applied Nutrition 38A, 17-22.

Rolland-Cachera, M. F. \& Bellisle, F. (1986). No correlation between adiposity and food intake: why are working class children fatter? American Journal of Clinical Nutrition 44, 779-787.

Rossander, L., Hallberg, L. \& Bjorn-Rasmussen, E. (1979). Absorption of iron from breakfast meals. American Journal of Clinical Nutrition 32, 2484-2489.

Syme, S. L. \& Berkman, L. F. (1976). Social class, susceptibility and sickness. American Journal of Epidemiology 104, 1-8.

Tanaka, P. A., Yeung, D. L. \& Anderson, G. H. (1987). Infant feeding practices: $1984-85$ versus $1977-78$. Canadian Medical Association Journal 136, 940-944.

Ten Statc Nutrition Survey (1973). Ten State Nutrition Survey: a pediatric perspective. Pediatrics 51 (6). 1095-1099. 
Truin, G. J., Konig, K. G., Ruiken, H. M. H. M., Vogels, A. L. M. \& Elvers, J. W. H. (1986). Caries prevalence and gingivitis in 5-, 7-, and 10-year-old school-children in the Hague between 1969 and 1984. Caries Research 20, 131-140.

Van Leishout, M. P. (1988). Health Behaviours of Pregnant Travelling Women in Peri-Urban Dublin. M.Sc. Thesis, Trinity College Dublin.

Wharton, B. A. (1981). Past achievements and future priorities - a view of present day practice in infant feeding 1980. In Nutrition and Health, a Perspective, pp. 169-181 [M. R. Turner, editor]. Lancaster: MTP Press.

Whitchead, M. (1988). The Health Divide. London: Penguin Books.

Yeung, D. L., Pennell, M. D., Hall, J. \& Leung, M. (1982). Food and nutrient intake of infants during the first 18 months of life. Nutrition Research 2, 3-12. 